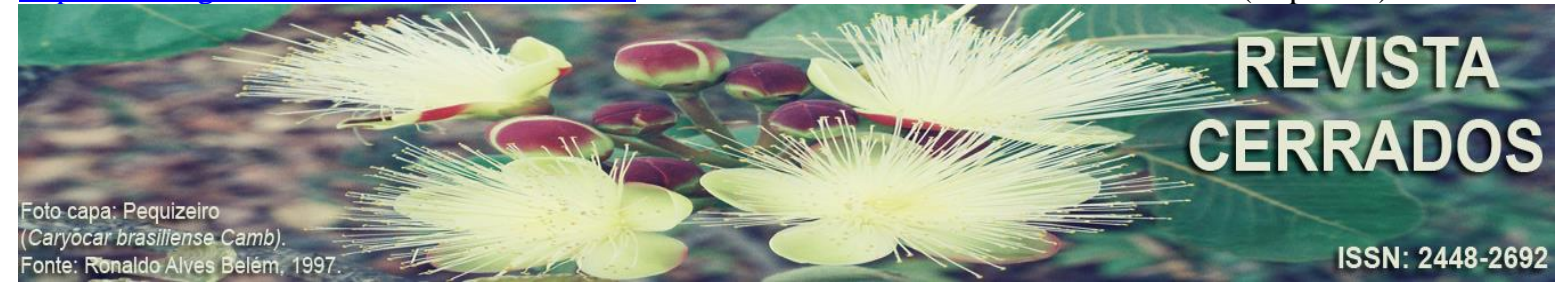

\title{
TERRITÓRIOS PESQUEIROS NA AMAZÔNIA: dinâmica de pescadores comerciais e de subsistência em comunidade ribeirinha da tríplice fronteira Colômbia-Brasil-Peru
}

\author{
FISHING TERRITORIES IN THE AMAZON RAINFOREST: the \\ dynamic of commercial and subsistence fishermen in riverside communities \\ in the triple border Colombia-Brazil-Peru
}

\section{TERRITORIOS PESQUEROS AMAZONICOS: dinamica de los} pescadores comerciales y de subsistencia en comunidad ribereña de la triple frontera Colombia-Brasil-Perú

\author{
Erlainy Joanna Souza de Paiva \\ Universidade Federal de Rondônia - UNIR, Porto Velho, Rondônia, Brasil \\ E-mail: <erlainypaiva@gmail.com>. \\ Ricardo Gilson da Costa Silva \\ Universidade Federal de Rondônia - UNIR, Porto Velho, Rondônia, Brasil \\ E-mail: <rgilson@unir.br>.
}

\section{RESUMO}

Analisa-se a dinâmica sociogeográfica da comunidade ribeirinha Terezina III, município de Tabatinga (localizada no estado do Amazonas), relacionada ao comércio do pescado e aos conflitos sociais decorrentes dessa atividade produtiva. $\mathrm{O}$ objetivo deste artigo é contribuir para o conhecimento referente ao modo de vida de pescadores do rio Solimões, na tríplice fronteira entre Brasil, Colômbia e Peru. Como procedimentos metodológicos, fez-se trabalhos de campo nas cidades de Tabatinga (Brasil) e Letícia (Colômbia), e na comunidade ribeirinha Terezina III (Brasil). Conclui-se que o acesso aos recursos pesqueiros deve ser ordenado pelo poder público, com participação social, de modo a fortalecer as comunidades ribeirinhas em seus territórios tradicionais.

Palavras-chave: Território. Atividades pesqueiras. Comunidades ribeirinhas. Amazônia.

\section{ABSTRACT}

It is analised the sociogeographic dynamics of riverside communities in the city of Tabatinga (located in the Amazon state), related to the fish trade and the social conflicts resulting from 
this productive activity. The purpose of this article is to contribute to the knowledge concerning the way of life of fishermen on Solimões River, on the triple border among Brazil, Colombia and Peru. As methodological procedures, fieldwork was carried out in the cities of Tabatinga (Brazil) and Leticia (Colombia), and in the riverside community Terezina III (Brazil). It has been concluded that access to fishing resources must be ordered by the public authorities, with social participation, in order to strengthen the riverside communities in their traditional territories.

Keywords: Territory. Fishing activities. Riverside communities. Amazon rainforest.

\section{RESUMEN}

Se analiza la dinámica sociogeográfica de la comunidad ribereña Terezina III, del municipio de Tabatinga (ubicado en estado del Amazonas), relacionada con el comercio pesquero y los conflictos sociales derivados de esta actividad productiva. El propósito del artículo es contribuir para el conocimiento del modo vivido por los pescadores del río Solimões, en la triple frontera entre Brasil, Colombia y Perú. Como procedimientos metodológicos, lo hicimos el trabajo de campo en las ciudades de Tabatinga (Brasil) y Letícia (Colombia), y en la comunidad ribereña de Terezina III (Brasil). Se concluye que el acceso a los recursos pesqueros debe ser ordenado por las autoridades públicas, con participación social, a fin de fortalecer las comunidades ribereñas en sus territorios tradicionales.

Palabras clave: Territorio. Actividades pesqueras. Comunidades ribereñas. Amazonas.

\section{INTRODUÇÃO}

No mundo amazônico, grande parte cercado por florestas, rios e terras férteis, comunidades ribeirinhas desenvolvem modos de vida distintos, marcados pela imprevisibilidade da natureza que rege suas atividades de trabalho. A pesca comercial crescente, sobretudo na Região Norte do Brasil, trouxe possibilidades de trabalho e renda para diversas famílias ligadas às dinâmicas das águas. Contudo, tais atividades ampliam os impactos no meio natural quando ameaçam o equilíbrio da ictiofauna explorada.

$\mathrm{Na}$ Amazônia brasileira as atividades da pesca de subsistência e da pesca comercial em diversos ambientes aquáticos, sobretudo nos rios e lagos, é uma atividade extrativa que movimenta cerca de 285 milhões de dólares como renda bruta (PETRERE, 1985). A economia da pesca no rio Solimões tem-se desenvolvido significativamente nos últimos anos (MORAES; SCHOR; ALVES-GOMES, 2010a). A cidade de Manaus no Estado do Amazonas concentra um dos maiores polos de comercialização pesqueira na região norte do Brasil, recebendo desembarque de pescado de diversos locais da região (RUFINO, 2005). 
PAIVA, E. J. S.; SILVA, R. G. C.

Territórios pesqueiros na Amazônia:dinâmica de pescadores comerciais e de subsistência em comunidade ribeirinha da tríplice fronteira Colômbia-Brasil-Peru

Tradicionalmente, além de pertencer a uma das expressões identitárias das sociedades amazônicas, representa uma atividade comercial importante que cresceu razoavelmente nas últimas décadas. Analisar os territórios pesqueiros existentes na região Amazônica demanda estudos voltados, principalmente, às organizações sociais que se constituíram e continuam exercendo seus trabalhos com a pesca.

A cidade brasileira de Tabatinga (localizada no oeste do Estado do Amazonas), situa-se na tríplice fronteira (Figura 1), onde se localizam as cidades de Letícia (Colômbia) e o distrito de Santa Rosa (Peru); são esses três núcleos urbanos que formam a tríplice fronteira. Evidentemente, o termo "Tríplice Fronteira" deriva da interseção das fronteiras de três países diferentes. No total, o Brasil possui nove tríplices fronteiras, seguido de Peru e Colômbia com cinco cada um.

Tabatinga e Letícia são cidades gêmeas, unidas por fronteira seca e possuem comércio bastante interligado por essa proximidade terrestre. Diferentemente do que ocorre com o distrito peruano de Santa Rosa (conhecido localmente como "Isla de Santa Rosa"), localizada na margem direita do Solimões, é fronteira dividida pelo rio Solimões/Amazonas. A conexão entre Santa Rosa e as duas cidades faz-se por meio de transporte fluvial; dura em média 7 minutos o translado de canoa motorizada (motor 15hp), saindo do porto de Tabatinga ou Letícia. Como é dito na localidade "é só atravessar o rio".

Ambas estão localizadas na região do Alto Solimões/Amazonas, situadas praticamente no centro da grande floresta amazônica e compartilham, além de costumes, crenças, culinárias, cultura mesclada, o caudaloso rio Solimões, repleto de bens culturais materiais e imateriais que modelam a dinâmica vivida por pescadores, agricultores, comerciantes e indígenas das etnias Ticuna e Kambeba (também conhecidos por Omágua). Na parte oeste do município de Tabatinga está localizada a terra indígena Umariaçu, protegida pela FUNAI, que abriga índios da etnia Ticuna e Kambeba.

A população da tríplice fronteira tece sua vida ligada às águas brancas (barrentas) do Solimões/Amazonas, rio nascido nas Cordilheiras dos Andes/Peru que apresenta ao longo de sua extensão ambientes territorializados sobretudo por populações ribeirinhas e caboclas, realidade que se justifica pelas terras férteis de várzea e pela fartura presente nos rios que é suporte necessário à dieta alimentar dessas populações. 
PAIVA, E. J. S.; SILVA, R. G. C.

Territórios pesqueiros na Amazônia:dinâmica de pescadores comerciais e de subsistência em comunidade ribeirinha da tríplice fronteira Colômbia-Brasil-Peru

Figura 1: Localização da tríplice fronteira entre Tabatinga (Brasil), Letícia (Colômbia) e Santa Rosa (Peru).

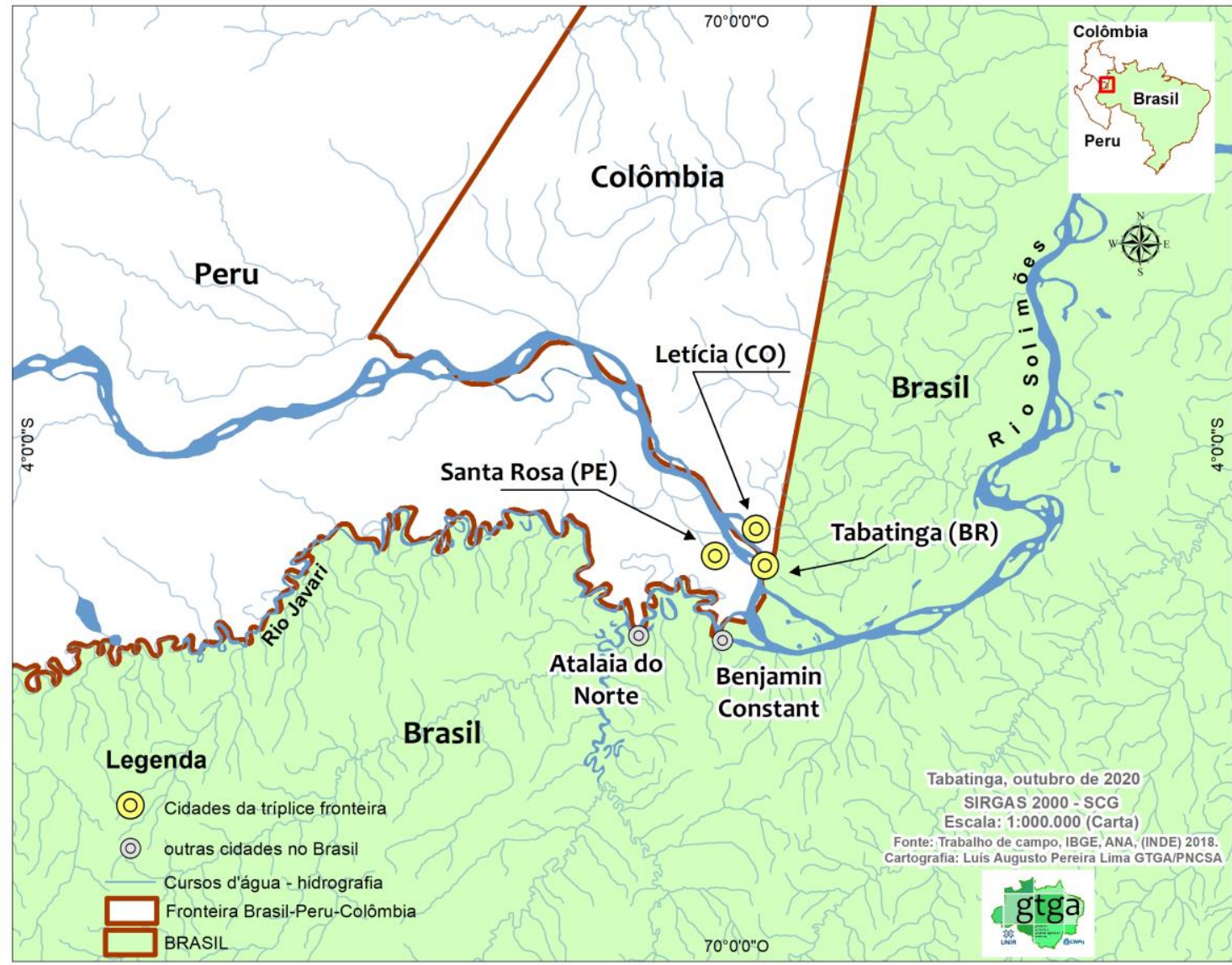

Fonte: autores, 2020.

A região do Alto-Solimões, na qual se insere o município de Tabatinga (Figura 1), aparece como um dos principais referenciais de desenvolvimento da atividade pesqueira para fins comerciais (PROVARZEA, 2005). O território de pesca, por ser um espaço com fluidez (diferente dos espaços terrestres que são fixos), dado a vaga e imaginária demarcação territorial (não há barreiras físicas) que limita os ambientes aquáticos nesta área fronteiriça, vivencia disputas entre as modalidades de pesca comercial versus subsistência; comercial versus comercial, que, consequentemente, tem modificado a realidade dos pescadores e comunidades ribeirinhas que dependem diretamente desta atividade produtiva.

Nesses territórios, as comunidades locais são fornecedoras de pescados para os centros urbanos da região e, sobretudo, para o exterior (capital da Colômbia), tornando-se, assim, um dos principais polos do setor comercial da pesca regional (MORAES; SCHOR; 
ALVES-GOMES, 2010a, 2010b; MORAES, 2012). Segundo Cruz (2007), a pesca no rio Solimões se intensificou devido à procura de bagres pelos grandes frigoríficos que estocam o pescado para exportação, sendo que esta espécie perfaz cerca de 95\% da pescaria existente hoje na Amazônia brasileira, colombiana, peruana, boliviana e venezuelana.

A principal destinação dos bagres pescados no rio Solimões é a Colômbia, pois existe um tabu alimentar em torno do consumo de bagres pelos amazonenses (BARTHEM; GOULDING, 1997). A cidade Letícia (Colômbia) é grande importadora de pescados oriundos de águas brasileiras, capturados por pescadores brasileiros, principalmente os peixes de couro (ou peixes lisos) como o surubim (Pseudoplatystoma fasciatum) e o mapará (Hypophthalmus spp), que possuem significativo valor comercial voltado para o abastecimento dos restaurantes locais que atendem turistas e demais consumidores da região (PAIVA, 2018, 2019).

Por outro lado, além da pesca comercial gerar conflitos pela posse dos recursos pesqueiros, também possibilita, em uma segunda esfera, a exploração insustentável do ambiente com a realização contínua de capturas de pescados. Nesse sentido, alguns impactos ambientais locais se fazem sentir, como por exemplo, a diminuição dos estoques de peixes em espaços próprios à captura do pescado para subsistência familiar (PAIVA, 2019). Essa é a realidade vivida pelos moradores da comunidade ribeirinha Terezina III desde a intensificação da pesca comercial após o fim do manejo pesqueiro no ano de 2018. A médio prazo, essa situação acarreta diversos problemas às comunidades locais, principalmente no que se refere ao campo de trabalho, à economia da pesca.

Assim, podemos dizer que o ser humano, como ser social, a pesca, como atividade de trabalho, e o território, como objeto de disputa, constituem elos que unem e, ao mesmo tempo, separam esses três países fronteiriços. Pela dinâmica que cerca as atividades de pesca, não podemos tomar como absoluto o cenário de hoje, tendo em vista as transformações que ocorrem em pouco espaço de tempo, contudo, podemos afirmar que este é o estado atual que se encontra esta área marcada por conflitos territoriais, desequilíbrio ambiental e exploração pesqueira.

Nesse sentido, o objetivo deste artigo é contribuir para o conhecimento do modo de vida dos pescadores que habitam a comunidade ribeirinha Terezina III, localizada às margens do rio Solimões, na tríplice fronteira entre Brasil, Colômbia e Peru, especificamente na cidade brasileira de Tabatinga, com foco nos conflitos territoriais decorrente da economia 
Territórios pesqueiros na Amazônia:dinâmica de pescadores comerciais e de subsistência em comunidade ribeirinha da tríplice fronteira Colômbia-Brasil-Peru

pesqueira. Para isso, adotou-se os seguintes procedimentos metodológicos: trabalhos de campo realizados nas cidades de Tabatinga (Brasil) e Letícia (Colômbia), especialmente nos mercados de peixes das respectivas cidades; trabalho de campo realizado na comunidade ribeirinha Terezina III (Brasil); diálogos, entrevistas e registros fotográficos da paisagem local, das famílias e dos trabalhos comunitários com a pesca; revisão bibliográfica e documental inerente à temática.

De modo geral, o texto está estruturado, além desta introdução e das considerações finais, em três seções. Na primeira, problematiza-se o processo social a partir do conceito de territórios pesqueiros e comunidades ribeirinhas, os quais entende-se como mais adequados à orientação da pesquisa. Em seguida, analisa-se a economia da pesca na tríplice fronteira, destacando os atores, as principais espécies de peixes comercializadas e os dilemas para as comunidades ribeirinhas, para, na seção posterior, problematizar conflitos decorrentes das pressões nos territórios pesqueiros de Terezina III. Conclui-se o crescimento do comércio regional e internacional na tríplice fronteira amplia, sobremaneira, as pressões econômicas nos territórios tradicionais das comunidades ribeirinhas, de modo a exigir mais atenção do Estado, dado as características geográficas do extremo oeste brasileiro.

\section{Territórios pesqueiros e comunidades ribeirinhas}

A expansão e a intensificação da pesca comercial, nos últimos 40 anos, acabaram por transformar a tecnologia empregada na pesca e na produção e, também, por mudar os tipos de produtos pesqueiros e as características do pescador comercial na Amazônia (ALMEIDA, 2006; MORAES; SCHOR; ALVES-GOMES, 2010a; SILVA, 2012; PAIVA, 2018). Nesse sentido, podemos perceber que na Amazônia brasileira, mundialmente conhecida pela vasta diversidade ecossistêmica de fauna e flora, está em transformação o modo de exploração dos recursos pesqueiros, uma das atividades produtivas mais importantes para as comunidades ribeirinhas, cujo trabalho, renda e reprodução social, em boa parte, derivam da economia da pesca.

Antes disso, compreende-se que os recursos pesqueiros "são todas as formas vivas que tenham na água o normal ou mais frequente meio de vida, juntamente com um definido interesse econômico" (PAIVA, 2004, p. 1). Torna-se importante destacar as características 
PAIVA, E. J. S.; SILVA, R. G. C.

Territórios pesqueiros na Amazônia:dinâmica de pescadores comerciais e de subsistência em comunidade ribeirinha da tríplice fronteira Colômbia-Brasil-Peru

básicas do recurso pesqueiro, não só como recurso natural renovável, como também sendo um recurso natural de propriedade comum e de livre acesso (ABDALLAH, 1998, p. 15), o que demanda políticas de gestão do território para conservar os recursos naturais e as atividades econômicas sustentáveis. Em relação aos recursos de propriedade comum, as instituições definem regras sobre quem tem acesso a um determinado recurso, o que e como pode ser explorado este recurso e quem participa nas decisões-chave sobre essas questões e sobre a transferência de direitos e deveres para com os outros (PAIVA, 2004).

Entendemos como de livre acesso o recurso pesqueiro encontrado na natureza, como os que estão presentes no rio Solimões, sujeitos a regulamentações estaduais e federais para uso e apropriação de vários grupos de usuários (pescadores comerciais, de subsistência, esportivos, etc.). Diferentemente ocorre com os recursos de acesso privado, como os cultivados em cativeiro, que não possuem regulamentação para que sejam explorados por diferentes grupos de usuários não reconhecidos como proprietários.

Pela dinamicidade dos pesqueiros em habitats "livres", como no caudaloso rio Solimões/Amazonas, entende-se que estes recursos não reconhecem fronteiras. Contudo, o ser humano, como ser racional e político, sabe e reconhece os limites territoriais, mas, conforme verificado em trabalhos de campo, o crescimento da economia da pesca em lagos comunitários fechados, destinados à reprodução social das comunidades ribeirinhas, tende a prejudicar essas comunidades, ampliando a natureza dos conflitos territoriais.

Dessa forma, não há suficiente vigilância na fronteira, sendo um espaço de fluxo econômico que, por vezes, ignora os limites políticos do território nacional. Na hipótese de viverem somente em águas de domínio público, ou quando nestas se encontram os pescados, estes constituem recursos públicos, cuja exploração está sujeita às disposições do país que tem o domínio territorial dessas águas (PAIVA, 2004). Essa característica do recurso pesqueiro, de ser um bem público, de propriedade comum e de livre acesso, pode implicar no advento da sobrepesca, propiciando a sua exaustão (RAGGI ABDALLAH, 1998, p. 33).

Em várias regiões de pesca na Amazônia, sobretudo nos rios do Estado do Amazonas, tanto os pescadores profissionais quanto pescadores tradicionais das comunidades ribeirinhas vivenciam períodos de interrupção da atividade, o chamado período de defeso, que tem como objetivo garantir a reprodução de diversas espécies, sendo necessário a ação do estado no regramento da atividade produtiva da pesca. 
Territórios pesqueiros na Amazônia:dinâmica de pescadores comerciais e de subsistência em comunidade ribeirinha da tríplice fronteira Colômbia-Brasil-Peru

De igual importância, esse processo de interrupção, mesmo que por breve período de tempo, tem propiciado diversos conflitos na exploração dos recursos pesqueiros, disputados entre diversas categorias, das quais destacamos em Tabatinga: a) pescadores de subsistência; b) pescadores comerciais; c) pescadores comerciais e de subsistência (simultaneamente). Em tais situações, abre-se um debate referente aos significados da natureza e da vida comunitária em função das pressões econômicas por determinado recurso. Essa questão pode ser analisada a partir do conceito de território, que ajuda a compreender as tramas conflitivas que enredam os tensionamentos em comunidades ribeirinhas (PAIVA, 2018 e 2019).

Nesse sentido, o debate nas ciências humanas referente aos conflitos socioambientais e/ou socioterritoriais tem na categoria território o caminho teórico para compreender as nuances dos processos políticos que atingem os espaços coletivos de comunidades tradicionais, a exemplo das comunidades ribeirinhas na Amazônia. Em Raffestin (1993), percebe-se o território como resultado de uma ação conduzida por um ator sintagmático (seja o Estado, empresas, movimentos sociais, organizações da sociedade civil, dentre outros), pois somente com a apropriação de um espaço concreto ou abstratamente é que há territorialização, efetivação de um projeto de território. Quando um recurso da natureza se torna mais atrativo à economia, quase sempre a aceleração do processo produtivo leva a exaustão, o que pode resultar em conflitos diversos, dado a diversidade de atores que são mobilizados nesse processo.

Em Gottmann (1975), para além da dimensão política que o território assume na ação do Estado, dado o reconhecimento da teoria da soberania no âmbito das relações internacionais que estruturam o Estado-nação, o território é tanto recurso quanto morada. Essa dupla dimensão implicar reconhecer que as lógicas inerentes aos processos modeladores se diferenciam conforme as referências que os atores sociais, os atores sintagmáticos, têm para com o território. Para o capital e Estado, o recurso assume a perspectiva econômica, enquanto que para as comunidade ribeirinhas é, sobretudo, morada, lugar do habitar, da copresença, do trabalho e da reprodução social, o que implica associar dimensões que integram tanto o trabalho quanto os direitos sociais, direitos humanos e territoriais (COSTA SILVA; NEVES, 2018; CUNHA; COSTA SILVA, 2019). 

ribeirinha da tríplice fronteira Colômbia-Brasil-Peru

De tal modo, o território é um espaço onde ocorre delimitações políticas que implicam em manifestações do poder, que pode gerar ou não conflitos entre os atores que o vivenciam, ou que se apropriam subjetivamente e efetivamente desse espaço. A apropriação material e imaterial é ressaltada por Saquet (2007) e Haesbaert (2014), ao argumentarem que o universo social do território comporta elementos imateriais correlatos às condições de existências dos grupos sociais, sendo, portanto, condição política para viver e defender o espaço coletivamente apropriado.

O território pode ser aprendido, ao menos, em três processos socioespaciais, conforme síntese de Costa Silva e Neves (2018, p. 638): o território sempre é uma área apropriada e/ou dominada; sempre expressa projetos de usos e de construção de territorialidades; sempre é gestado por sujeitos, atores, agentes, instituições, de modo que não há território sem controle político. Por conseguinte, o território pesqueiro, utilizado especificamente por pescadores artesanais, demonstra a identidade do espaço vivido, as territorialidades das comunidades ribeirinhas em sua relação com a natureza, além de ser espaço constituinte de moradia e trabalho (CUNHA; COSTA SILVA, 2019).

Esses grupos aparecem sob o conceito de "ribeirinhos", que segundo Diegues (1994) refere-se àqueles que andam pelos rios. O rio constitui a base de sobrevivência dos ribeirinhos, fonte de alimento e via de transporte, graças, sobretudo às terras mais férteis em suas margens. Já a ideia de comunidade aparece sob o prisma de vivência em coletividade, que algumas sociedades apresentam e tendem a ser reconhecidas como tradicionais. A construção do saber tradicional possui inúmeras distinções. É um saber alicerçado na vivência dos indivíduos, nas suas relações pessoais, sociais e, também, com a natureza. Pode-se afirmar que o conhecimento tradicional é fruto do trabalho e das descobertas de um grupo, o que justifica sua riqueza e diversidade (DIEGUES, 1994). Desse modo, portanto, este artigo dialoga com a vivência de diferentes categorias de pescadores em comunidades ribeirinhas, que ao tecerem suas dinâmicas de trabalho, estruturam todo o território, salientado pela conflituosa área na tríplice fronteira.

Nos estudos referentes às atividades pesqueiras, compreende-se que "o território pode ser visto ora conforme a lógica zonal, a partir do momento em que há a caracterização de Zonas de pesca reconhecidas pelos pescadores, ora como uma lógica reticular, devido a extensa mobilidade que caracteriza a atividade pesqueira" (SILVA, 2012, p. 29). Nesta 
concepção, os pescadores podem ser conhecidos e conceituados, segundo Ramalho (2016, p. 6), como profissionais que fazem da "pesca seus meios de vida" e são portadores de "um jeito de ser que é somente deles", um modo de vida pleno de especificidades socioculturais. O pescador é "o cara que sabe usar e desenvolver as pescarias", por conhecer e deter um ofício que é aprendido junto a seus familiares, porque "a pesca é uma profissão de família", uma atividade ancestral, comunitária; neste potencial:

O pescador é oportunidade socioeconômica, hábito de classe, costume, ideologia e relações sociais comunitárias ou com outros grupos, onde produz e reproduz sua singularidade em oposição ou em complementaridade com outros segmentos sociais no tempo e no espaço. Ademais, ser pescador é encontrar-se inserido em uma determinada relação na estrutura social, de comando do capital, cujas tensões alimentadas pelos desejos de autonomia, resignações e subordinações estão no dia a dia (RAMALHO, 2016, p. 20).

Inerente aos espaços individuais (privado) ou coletivo (comunal ou grupal) onde são realizadas apropriações do recurso pesqueiro, não se deve pensar em delimitação espacial aleatória. Pode-se afirmar que os territórios pesqueiros, enquanto espaço de uso, foram formados a partir das relações sociais materializadas na delimitação territorial do recurso natural que assegura a economia da pesca. Assim, as ações de "apropriação" são importantes na produção do território, visto que são essas ações que passam a expor o espaço dominado por determinado grupo, na medida em que "isto transforma o território num trunfo particular como espaço político, campo de ação de diversas territorialidades, ação da população e apropriação dos recursos por essa população" (SILVA, 2012, p.19).

Num primeiro momento, o território tradicional pertence às comunidades ribeirinhas, sendo seu usufruto acionado tanto ao trabalho quanto à reprodução social do grupo. Em seguida, no segundo momento, por seu recurso natural objeto da economia comercial, o território tradicional é disputado pelos agentes do comércio local e regional da pesca, de modo a causar os conflitos no uso do território. As lógicas políticas do território emergem desses processos conflitivos, ampliando a escala dos conflitos e os estranhamentos para com a natureza e o grupo social (COSTA SILVA, 2014; RAPOZO, 2015).

Aos territórios de pesca ou pesqueiros são atribuídas relações de poder, isto é, podem possuir 'donos', ou famílias que são 'donas', sendo que várias famílias aparentadas podem utilizar do mesmo recurso pesqueiro, derivando muitas vezes em acordos entre 
Territórios pesqueiros na Amazônia:dinâmica de pescadores comerciais e de subsistência em comunidade ribeirinha da tríplice fronteira Colômbia-Brasil-Peru

familiares ou membros das comunidades (RUFFINO, 2005, p.18). Nesse caso, não pensamos no território apropriado de modo aleatório, mas sim, pela importância, representação, necessidade e, sobretudo, por ser produto de desejo social, caracterizado e territorializado a partir de seus usos e significações.

De modo geral, entende-se por comunidades ribeirinhas os grupos sociais que habitam próximas às margens dos rios e que "vivem basicamente em função da caça, pesca, agricultura e criação de animais de pequeno porte. Não são isoladas do restante do mundo, pois mantêm comunicações e relações diretas com centros urbanos e comunidades próximas" (PAIVA, p. 45).

As condições sociogeográficas e culturais das comunidades ribeirinhas indicam que o universo social na Região Amazônica é povoado por formas diferentes na relação com a natureza, de modo que as comunidades ribeirinhas constituem a síntese que o grupo humano produziu como condição necessária à existência neste mundo das águas e das florestas. $\mathrm{Na}$ relação das comunidades ribeirinhas é por demais sabido que o conhecimento popular compõe o alicerce que condicionam os grupos a viver, produzir e conhecer o meio geográfico, qualidade formada no processo histórico que qualificam a formação socioespacial da Amazônia brasileira (SCHERER, 2004; ADAMS, 2006; RAPOZO, 2015).

\section{Atividade pesqueira na tríplice fronteira}

Em 1768 o governo colonial deslocou um grupo de indígenas cristianizados para a localidade de Tabatinga, com o proposito comercial e político de erguer uma pequena feitoria (MACHADO, 1989). Em 1770 foi erguido o forte de São Francisco Xavier de Tabatinga, pelo Sargento-Mor Domingos Franco, com vistas a assegurar a posse do território as vésperas da assinatura do tratado de Santo Ildefonso (1777), o que veio a dar origem ao povoado (REZENDE, 2006). Tabatinga foi considerada povoado em 1840.

O município de Tabatinga está situado no interior do Estado do Amazonas, possui $3.266,062 \mathrm{~km}^{2}$ de área territorial, assentada em uma planície fluvial com 73 metros de altitude e clima equatorial. Localiza-se na parte ocidental da Amazônia brasileira, margem esquerda do rio Solimões/Amazonas, especificamente na mesorregião do Sudoeste amazonense, microrregião do Alto Solimões. É um dos municípios do interior do Amazonas mais distantes 
Territórios pesqueiros na Amazônia:dinâmica de pescadores comerciais e de subsistência em comunidade ribeirinha da tríplice fronteira Colômbia-Brasil-Peru

da capital Manaus, com $1.106 \mathrm{~km}$ de distância em linha reta. Entre as duas cidades, o tempo médio de voo comercial (via empresa Azul) é de 1h55min, enquanto o transporte fluvial (barco, no trecho Manaus-Tabatinga) leva-se, aproximadamente, sete (07) dias.

Nos dados do último Censo Demográfico, Tabatinga apresentou 52.272 habitantes, com densidade demográfica de $16,21 \mathrm{hab} / \mathrm{km}^{2}$. Ressalta-se as dificuldades socioeconômicas do município (em 2015, os alunos dos anos iniciais da rede pública da cidade tiveram nota média de 4.4 no IDEB), infraestrutura precária (com cerca $21.6 \%$ de domicílios com esgotamento sanitário adequado), serviços básicos, base produtiva, governança e governabilidade subdesenvolvidas, o que resultou no IDHM (Índice de Desenvolvimento Humano Municipal) de 0,616 (nível médio) no ano de 2010, influenciado, principalmente, pelo peso dos serviços públicos na composição do emprego e nos salários. O PIB per capita em 2017 foi de $R \$ 7.255,96$, o que significa ocupar a $46^{a}$ posição na escala estadual (IBGE, 2020).

Embora conte com a vigilância e prevenção das polícias civis, federal, militar e forças armadas, Tabatinga, sobretudo no ano de 2007, foi uma cidade marcada por muitos homicídios decorrentes do narcotráfico. Pela facilidade na entrada de entorpecentes oriundos de zonas produtoras do Peru e Colômbia, tornou-se uma das rotas principais do fluxo de drogas no Brasil. Nos dias atuais Tabatinga ainda é vista como local perigoso pelo alto índice de criminalidade e baixo desenvolvimento social. Somente em 2017, foram 22 homicídios registrados na cidade. Nos últimos 5 anos, a quantidade de roubos dobrou, saltando de $51 \mathrm{em}$ 2013 para 103 em 2017 em Tabatinga. Os furtos também aumentaram de 68 casos em 2013 para $139 \mathrm{em} 2017$.

O Atlas da Violência - Retrato dos Municípios Brasileiros 2019, elaborado em parceria com o Fórum Brasileiro de Segurança Pública, mostra que houve um crescimento das mortes nas regiões Norte e Nordeste influenciado, principalmente, pela guerra do narcotráfico, a rota do fluxo das drogas e o mercado ilícito de madeira e mogno nas zonas rurais.

A cidade tabatinguense apresenta intenso comércio pesqueiro no mercado municipal local, fruto da produção advinda de pescadores comerciais de pequena escala e de pescadores de subsistência, que comercializam pequenas quantidades de excedentes. Ambos vivem em Tabatinga ou nas comunidades ribeirinhas próximas. A livre comercialização entre 
Territórios pesqueiros na Amazônia:dinâmica de pescadores comerciais e de subsistência em comunidade ribeirinha da tríplice fronteira Colômbia-Brasil-Peru

Tabatinga e Letícia facilitada pela ausência ou pouca fiscalização de órgãos de controle como a Agência Nacional de Vigilância Sanitária (ANVISA), IBAMA e Polícia Federal, faz com que a compra e venda de pescados entre as duas cidades se torne um comércio fora da legalidade. O comércio pesqueiro é impulsionado pelo "livre" fluxo econômico na tríplice fronteira, onde os três países dividem as águas do rio Solimões e nele desenvolvem, há bastante tempo, a pesca.

Segundo as pesquisas que realizamos para a elaboração deste artigo, no ano de 2019 em Tabatinga, o modo alimentar da população local é pautado no consumo de proteínas como pescados da própria região (gráfico 1) e carne bovina, suína e frango congelado que vem da capital Manaus. Segundo Barthem e Goulding (1997), as taxas de consumo de pescado na Amazônia são as maiores do mundo, com média estimada em 369g/pessoa/dia ou $135 \mathrm{~kg} / \mathrm{ano}$ em certas áreas do alto Solimões e alto Amazonas, constituindo-se na principal fonte de proteínas para as populações humanas residentes.

Ainda segundo as pesquisas, o peixe aparece como principal fonte de proteína consumida na tríplice fronteira. A pesca de subsistência apresenta maior diversidade de capturas na época de cheia e vazante do que nas épocas de seca e enchente, devido a maior disponibilidade de hábitats para os peixes que passam a explorar as matas alagadas. Já a pesca comercial tem o pico de produção no primeiro semestre do ano, geralmente entre os meses de abril e junho, período de enchente-cheia, coincidente com a migração de algumas espécies de Characiformes, como jaraquis, matrinxã, pacus e curimatã (FREITAS e RIVAS, 2006).

Através da pesquisa de campo, realizada no primeiro semestre de 2019 (período de enchente-cheia), no mercado municipal de Tabatinga, foram entrevistadas vinte (20) pessoas de cada categoria (vendedor e consumidor), totalizando 40 entrevistados no geral. Dentre os 40 entrevistados, temos brasileiros, colombianos e peruanos que compram/vendem peixes no mercado municipal de Tabatinga por ser mais barato. Unimos as três nacionalidades e dividimos somente em dois grupos: consumidor e comerciante, para facilitar o uso dos dados. 
PAIVA, E. J. S.; SILVA, R. G. C.

Territórios pesqueiros na Amazônia:dinâmica de pescadores comerciais e de subsistência em comunidade ribeirinha da tríplice fronteira Colômbia-Brasil-Peru

Gráfico 1: Espécies de peixes mais consumidos e comercializados por colombianos, peruanos e brasileiros da tríplice fronteira (2019)

\section{Espécies consumidas/comercializadas no mercado Municipal do peixe em Tabatinga}

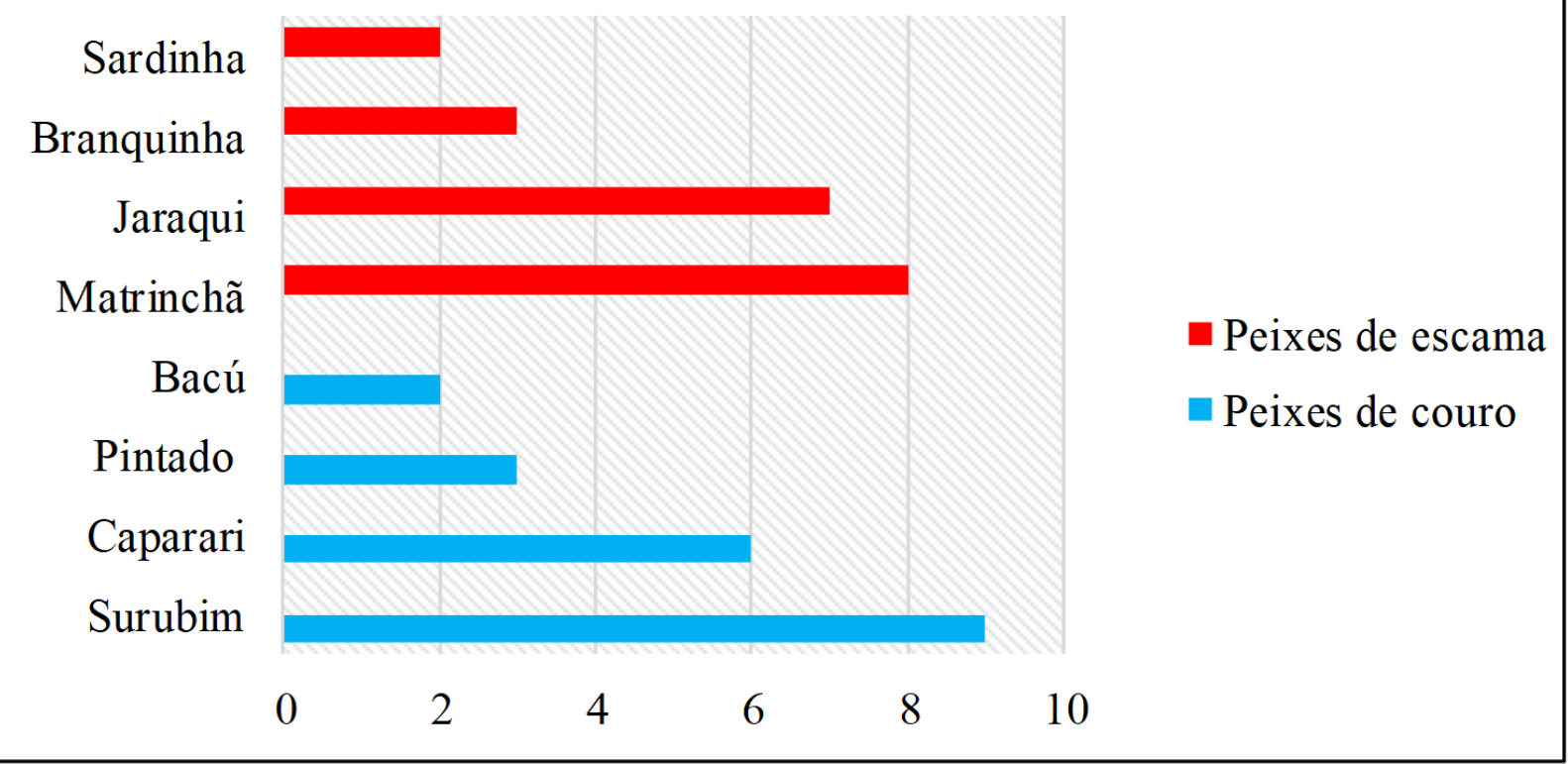

Fonte: Pesquisa de campo, Maio de 2019.

É preciso salientar que no mercado municipal do peixe em Tabatinga a venda do pescado não é realizada somente por brasileiros. Colombianos e peruanos também comercializam seu produto lá. Em outros pontos da cidade tabatinguense também podemos observar essa prática comercial, sobretudo na conhecida "feira do bagaço" (local para venda de frutas, verduras e legumes) em que a maioria dos comerciantes são peruanos.

Aos entrevistados da pesquisa foi feita a seguinte pergunta: quais espécies de peixes de escama e de couro que você mais compra/vende? Através das respostas, constatamos as espécies que aparecem com maior percentual de venda e consumo na tríplice fronteira são respectivamente: surubim, matrinchã, jaraqui e caparari (Gráfico 1). Observa-se que, em uma escala de 0 a 10, os peixes mais comercializados e consumidos, segundo sua classificação, são: Surubim (peixe de couro) e Matrinchã (peixe de escama).

$\mathrm{Na}$ época da pesquisa o surubim estava fora do período de defeso que ocorre entre novembro e março. Essa espécie de couro aparece com porcentagem significativa no comercio e consumo local devido ao agradável sabor e ser de médio porte. Segundo Freitas e 
Territórios pesqueiros na Amazônia:dinâmica de pescadores comerciais e de subsistência em comunidade ribeirinha da tríplice fronteira Colômbia-Brasil-Peru

Rivas (2006, p. 4), siluriformes de médio e grande porte como dourada, piraíba, surubim, caparari e pirarara tem maior parte da captura exportada para outros estados brasileiros e para o exterior. $\mathrm{O}$ tabu alimentar em torno do seu consumo entre a população amazonense faz com que apenas uma pequena parte desses peixes, geralmente surubins, siga para o comércio local, enquanto a maior parte é destinada à exportação, situação que configura uma estrutura de mercado mais complexa (BARTHEM e GOULDING, 1997).

Espécies escamosas, como a matrinchã, alimentam-se de frutinhas, sementes, insetos e pequenos peixes. Esses são os principais motivos que os tornam muito consumidos por tabatinguenses, por serem considerados "limpos" devido sua alimentação. Diferentemente das espécies de couro, que são conhecidas regionalmente por "urubu dos rios" porque são carnívoros e, segundo alguns mitos, alimentam-se de cadáveres que são jogados no rio Solimões. Isso significa que para os tabatinguenses é preferível consumir espécies escamosas (cultura alimentar). Já os colombianos e peruanos não tem essa crença e os consomem sem distinção, aliás, para eles é preferível espécies de couro por não conter quase espinhas.

A pesca excessiva realizada na região, voltada a abastecer o comércio nacional e internacional, tem ocasionado sérios problemas ambientais, sobretudo nos ecossistemas de lagos, que sofrem ações degradantes de pescadores comerciais, que visam espécies endêmicas (como pirarucu e tambaqui, que se reproduzem em lagos). Essa realidade tem ocasionado a inserção de medidas conservacionistas, como o manejo pesqueiro em lagos comunitários, por exemplo, criado para reestruturar ambientes afetados pelo desenvolvimento da pesca insustentável.

Com o intuito de amenizar os impactos gerados pela exploração, foram criados diversos órgãos governamentais que passaram a ser responsáveis por questões voltadas à conservação do ambiente pesqueiro. É necessário estabelecer, antes de tudo, que os rios e lagos federais são aqueles que: se estendem por mais de um Estado, fazem fronteira com países vizinhos, se estendem por países vizinhos ou estão no interior de imóveis federais ou sobre a faixa de $150 \mathrm{~km}$ das fronteiras do país (SCHWADE, 2019, p.111).

Assim, ficou a cargo do Instituto Brasileiro do Meio Ambiente e dos Recursos Naturais Renováveis - IBAMA (órgão federal responsável pelas políticas de proteção do meio ambiente no Brasil), o controle e fiscalização das medidas estabelecidas pela política de ordenamento pesqueiro. O objetivo dessa ação é fazer com que os recursos naturais 
Territórios pesqueiros na Amazônia:dinâmica de pescadores comerciais e de subsistência em comunidade ribeirinha da tríplice fronteira Colômbia-Brasil-Peru

pesqueiros sejam explorados racionalmente, de acordo com as normas e regulamentações estabelecidas para manter sua sustentabilidade (ABDALLAH, 1998).

A descentralização e compartilhamento entre o IBAMA (que tem o poder de fiscalização e ordenamento) e comunidades ribeirinhas (principais afetados) trouxeram melhorias para a inserção de medidas voltadas aos cuidados e proteção dos ambientes degradados, como ocorreu no manejo pesqueiro desenvolvido na comunidade Terezina III. Essas ações resultaram na aproximação entre o IBAMA e comunidades ribeirinhas. Consequentemente, tornou-se possível criar instruções normativas, gestão participativa e acordos de pesca como meio de gerir os recursos pesqueiros, contando com a participação dos usuários e do Estado, quando o projeto IARA (Instituto Amazônico de Manejo Sustentável dos Recursos Ambientais) passou a assumir tal atividade, por intermédio da parceria que já desenvolvia com o IBAMA, desde 1994.

A tomada de decisão conjunta entre o poder público (órgãos ambientais) e os usuários (pescadores e moradores de comunidades ribeirinhas) foi uma forma de melhoria no controle e fiscalização dos recursos, tendo em vista a grande extensão do espaço amazônico. A descentralização do poder de decisão garantiu maior participação dos moradores da Comunidade Terezina III , que passaram a ter "voz" para discutir sobre a realidade vivida, como também para apontar os fatores geradores de conflitos entre os pescadores de subsistência da comunidade, pescadores comerciais internos e externos. Assim, inicia-se um ponto de conflito pelo uso do território pesqueiro, uma vez que este passou a ser controlado e a ter restrições para o desenvolvimento da pesca comercial no lago comunitário.

O lago comunitário Caiau (Figura 2), localizado no território da Comunidade Terezina III, muito utilizado e de grande importância para as populações locais pela riqueza ictiológica, aparece como principal espaço de conflito entre as categorias de pescadores comerciais e de subsistência, uma vez que ele é disputado pelos recursos que nele existe, e não somente pela área que ocupa. 
PAIVA, E. J. S.; SILVA, R. G. C.

Territórios pesqueiros na Amazônia:dinâmica de pescadores comerciais e de subsistência em comunidade ribeirinha da tríplice fronteira Colômbia-Brasil-Peru

Figura 2: Localização do Lago Caiau e as comunidades brasileiras próximas à Tríplice Fronteira

(2019)

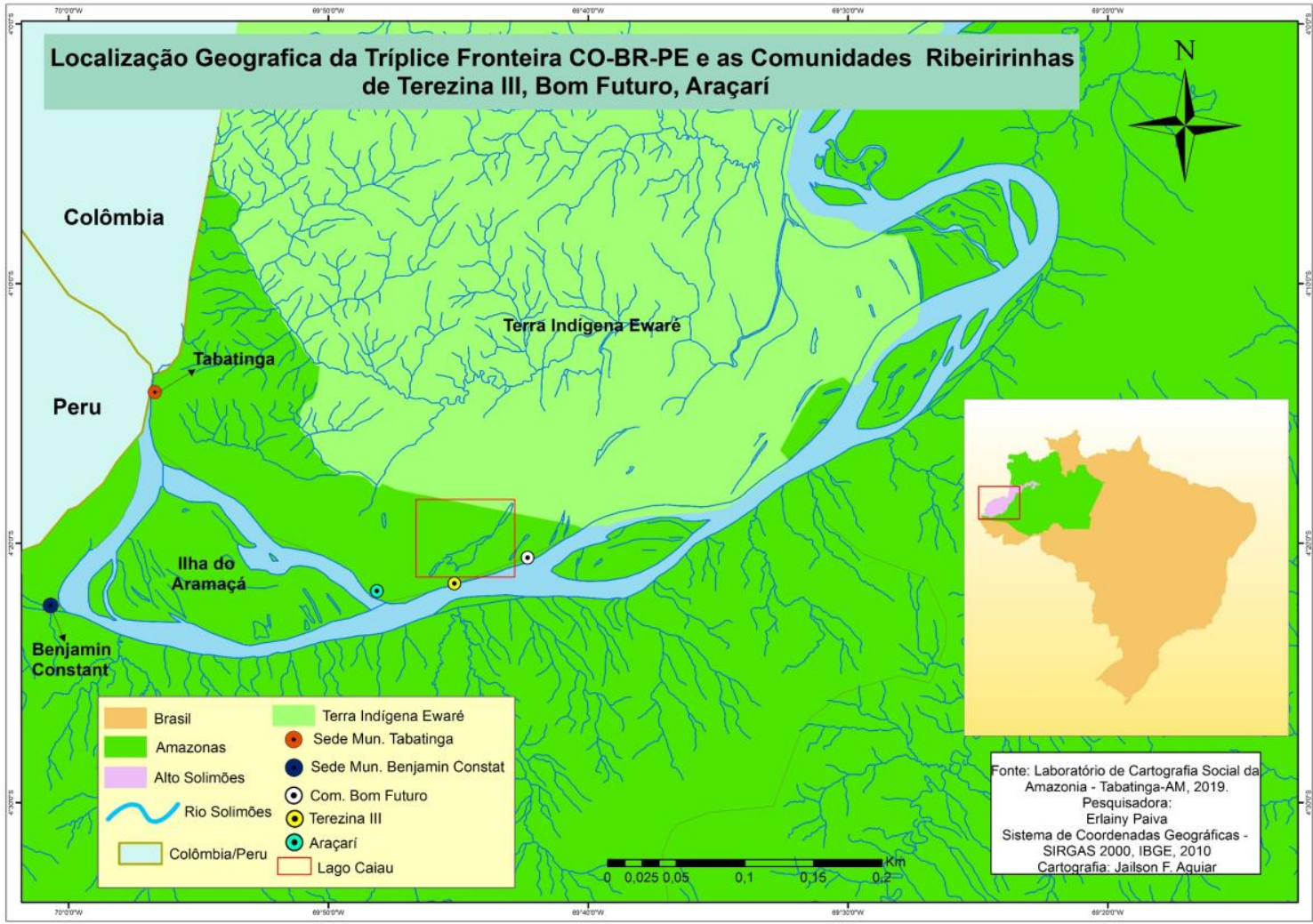

Fonte: Núcleo de Estudos Socioambientais da Amazônia - NESAM (2019).

O que mais tem gerado alvoroço entre os comunitários é a questão dos conflitos ocorridos com a presença de pescadores comerciais do Peru e da Colômbia, de modo que se torna mais difícil realizar mediações e restrições de acesso ao lago, porque esses agentes dificilmente acatam regras e respeitam limites territoriais.

Na região transfronteiriça, os conflitos entre pescadores das três nacionalidades se tornaram recorrentes, principalmente pela facilidade que a "fronteira molhada" oferece em decorrência da falta/pouca fiscalização pública. A intensa exploração pesqueira ocorrida nessa área de fronteira é potencializada pelo mercado consumidor regional e internacional, pois, além de abastecer os consumidores locais, grande parte dos peixes de couro capturados em águas brasileiras é destinado à exportação para a capital colombiana - Bogotá. Segundo Paiva (2019), o fluxo internacional de pescado (peixes de couro) representa $70 \%$ do comércio em Tabatinga, enquanto o consumo local responde por $30 \%$ da produção. 
PAIVA, E. J. S.; SILVA, R. G. C.

Territórios pesqueiros na Amazônia:dinâmica de pescadores comerciais e de subsistência em comunidade ribeirinha da tríplice fronteira Colômbia-Brasil-Peru

As principais espécies destinadas à comercialização internacional têm características peculiares: são peixes de couro e de grande porte como o surubim (Pseudoplatystoma corruscans) (Figura 3). Quase não há dados/informações de exportação de peixes escamosos para a cidade de Bogotá. Segundo os entrevistados, os peixes "miúdos" e de escamas possuem melhor comercialização no mercado local de Tabatinga.

Figura 3: Comércio de peixe nos mercados de Letícia (Colômbia) e Tabatinga (Brasil)
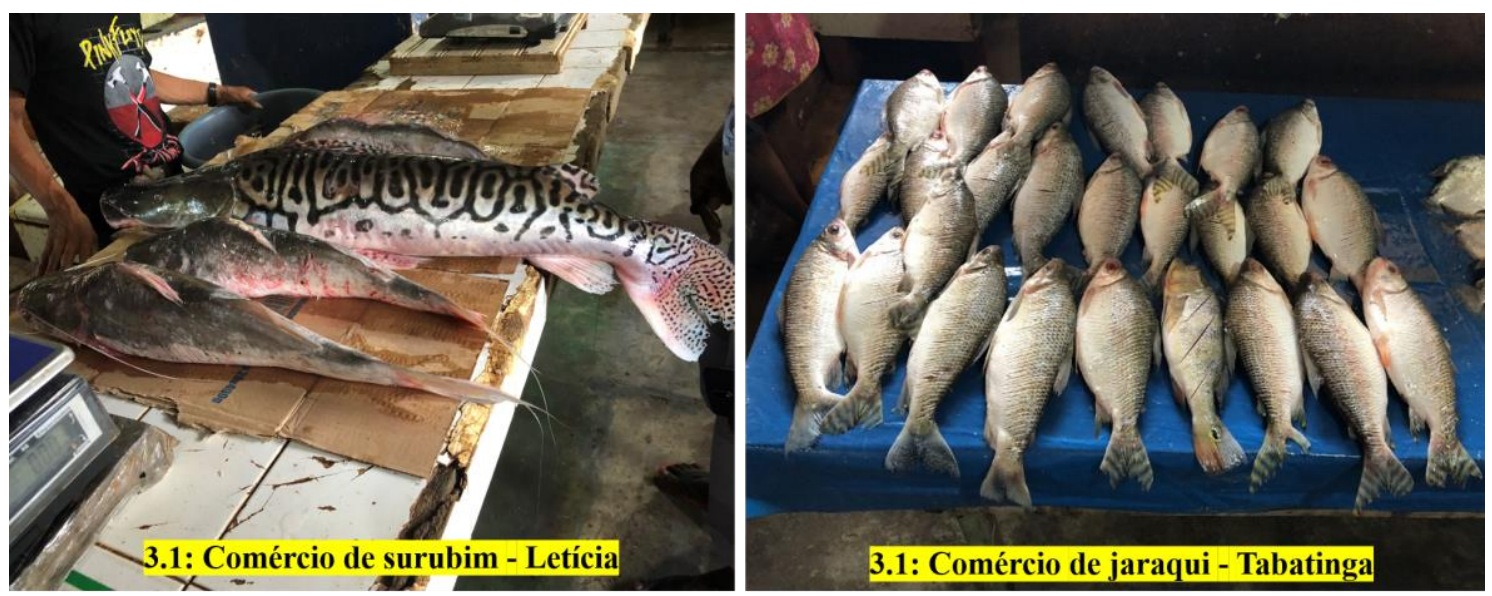

Fonte: Pesquisa de campo, 2019.

Assim, salienta-se que a comercialização pesqueira regional e internacional possue identidade quanto as espécies que o mercado consumidor tem preferência, assim, os pescadores procuram capturar espécies destinadas a cada um desses mercados, de modo que, logo após a captura, o peixe basicamente tem "destino certo", como podemos identificar no diálogo de muitos pescadores: "quando pegamos um surubim, na certa já sabemos que vamos vender em Letícia, porque lá compram rápido, ou vender para algum frigorífico" (Entrevistado 01).

A cadeia produtiva dos bagres conta com a participação de vários agentes que intermedeiam o processo. Em Tabatinga, a proximidade com o destino simplifica essa cadeia, permitindo que os próprios pescadores artesanais comercializem diretamente o seu pescado para as bodegas de Letícia (MORAES et al., 2010).

Grande parte do pescado que chega à mesa do consumidor local é oriunda da atividade realizada por pescadores comerciais (a pesca para esses tem finalidade principalmente profissional) e por aqueles que vendem os excedentes (para esses a pesca não 
PAIVA, E. J. S.; SILVA, R. G. C.

Territórios pesqueiros na Amazônia:dinâmica de pescadores comerciais e de subsistência em comunidade ribeirinha da tríplice fronteira Colômbia-Brasil-Peru

é uma profissão). Esses sujeitos vivem em comunidades ribeirinhas, ou na cidade de Tabatinga. Muitos pescadores que vão ao mercado da cidade vender os excedentes, não detêm grandes quantidades a ofertar, mas a venda colabora para o sustento das famílias e evita o desperdício do pescado.

Não há presença significativa de indústrias ou embarcações (com capacidade para armazenar mais de 1 tonelada) que realizam a atividade pesqueira na cidade de Tabatinga ou próxima a ela. Normalmente, as pescarias são realizadas por pescadores dos três países, em embarcações com motores a diesel e caixas de gelo que podem conservar até $500 \mathrm{~kg}$ de pescado por viagem. Os frutos da pesca são escoados nos mercados municipais de Letícia, Tabatinga, e uma parcela significativa, sobretudo os grandes bagres, é destinada ao mercado consumidor de Bogotá, através dos frigoríficos colombianos localizados em Leticia.

O mercado dos bagres possui lógica internacional para o Alto e Médio Solimões embora existam registros de mercado para esses peixes em Manaus que, entretanto, participa de outra rede que não a da exportação para Letícia (MORAES et.al., 2010). A produção do entorno de Tabatinga e Benjamim Constant é transportada em canoas dos próprios pescadores ou, no caso de Benjamim Constant, os "patrões" (donos das bodegas de Letícia com os quais os pescadores têm contrato) enviam embarcações para recolher o pescado nos frigoríficos locais (MORAES et al., 2010).

A complexidade que envolve os estudos acerca da geografia econômica da pesca na Amazônia fica evidente quando se consideram os valores que o peixe pode assumir tanto como produto de consumo quanto como mercadoria . Verifica-se que a produção pesqueira na tríplice fronteira se enquadra na perspectiva do circuito inferior da economia urbana proposta por Santos (1979), sendo, pois, uma economia que expande os trabalhos formal e informal, articulando o espaço ribeirinho com o espaço urbano da tríplice fronteira, o que resulta num dos principais ramos econômicos que envolve milhares de trabalhadores rurais que podem, assim, acessar uma renda para suas famílias. Caracteriza-se, sobretudo, pela escala local e regional dos fluxos mercantis do pescado, no qual, como bem expressou Gottmann (1975) e Santos (2000), o território apresenta-se tanto como recursos quanto como morada para os atores que participam da economia da pesca nesta região da Amazônia brasileira.

Sendo, pois, territórios pesqueiros, a dinâmica socioeconômica engendra os conflitos pelos recursos pesqueiros e pelo controle do território, dado a escala produtiva cada 
PAIVA, E. J. S.; SILVA, R. G. C.

Territórios pesqueiros na Amazônia:dinâmica de pescadores comerciais e de subsistência em comunidade ribeirinha da tríplice fronteira Colômbia-Brasil-Peru

vez demandada pelo mercado regional, o que tende a modificar as relações sociais que congregam o território. Assim, os conflitos e os estranhamentos nas comunidades ribeirinhas se instalam em função das variáveis externas que passam a influenciar e impactar o vivido territorial.

\section{Os conflitos pelo uso do território na Comunidade Terezina III}

A comunidade ribeirinha Terezina III está localizada a 23,672km de distância em linha reta de Tabatinga, margem esquerda seguindo o fluxo do rio Solimões/Amazonas. Para chegar à comunidade gasta-se em média 02h30min, no motor de $15 \mathrm{hp}$, saindo do porto de Tabatinga (somente se chega a ela utilizando transporte fluvial). Terezina III possui 151 habitantes (crianças, jovens, adultos e idosos) divididos em 51 famílias, que possuem representação religiosa católica, com apenas uma igreja na localidade. Há uma única escola chamada "Padre Anchieta", localizada na entrada da comunidade e atende séries do ensino primário, fundamental e médio.

Não há hospital ou unidade básica de saúde, somente há presença de dois agentes de saúde que realizam atendimentos básicos. Ao acontecer problemas de saúde graves, os pacientes são encaminhados para Tabatinga em um motor potente de $200 \mathrm{hp}$, destinado a atender casos graves e urgentes. Por estar em área de planície sujeita a inundações anuais durante o período da enchente que expande o rio Solimões/Amazonas, Terezina III passa a ter dois períodos distintos: cheia e seca (vazante), que interferem na produção agrícola e pesqueira local. As principais fontes de renda das famílias podem ser agrupadas em: pesca, agricultura, criação de animais de pequeno porte, extrativismo vegetal, emprego público, aposentados do INSS, beneficiários do bolsa família e seguro defeso. Para eles, a agricultura e a pesca são os principais meios de trabalho e renda.

Na comunidade está localizado o lago Caiau, de uso comum dos moradores de Terezina III, Araçari e Bom Futuro, que são próximas territorialmente. Contudo, há denúncias de que o lago também é utilizado por sujeitos alheios, sejam estes pescadores colombianos e peruanos. Tal fato fez com que as comunidades estabelecessem desde o ano de 2007 um acordo de pesca e, consequentemente, passaram a manejar o lago em 2015. Em 2017 o manejo fracassou e voltaram a realizar as mesmas práticas de exploração que levaram a 
Territórios pesqueiros na Amazônia:dinâmica de pescadores comerciais e de subsistência em comunidade ribeirinha da tríplice fronteira Colômbia-Brasil-Peru

diminuição dos estoques pesqueiros. Intensificou-se a partir daí conflitos entre os diferentes grupos de usuários.

A emergência de conflitos socioambientais decorrentes das atividades econômicas está frequentemente presente em qualquer território inserido em sociedades produtivistas e consumistas. Tais conflitos, contudo, podem ser compreendidos em inúmeras formas. Por exemplo, podemos analisá-los a partir das contradições existentes do comércio desigual e injusto entre países do atual capitalismo globalizado (PORTO, 2020, p. 11), ou da fragilidade institucional em regiões de fronteira, como se verifica na Amazônia (PAIVA, 2018, 2019), sendo este último, o ponto de análise neste artigo.

Por existirem numerosos pescadores e comunidades ribeirinhas na região estudada, e pela intensa atividade comercial realizada pelos mesmos, são originados conflitos pelo uso do território e pela posse dos recursos naturais existentes nesses territórios (RAPOZO, 2015). Sabe-se que espécies altamente lucrativas, como o Pirarucu (Arapaima gigas), são excessivamente procuradas e capturadas, e quando se reconhece que espécies como essas habitam ambientes singulares, como os lagos, esses espaços passam a ser o foco principal de atividades predadoras que buscam altos lucros, como atualmente ocorre no lago Caiau.

A realização de pescarias manifestamente insustentáveis nesses ambientes singulares que abrigam espécies muito procuradas, são, hoje, palco de conflitos. Normalmente, os conflitos ocorrem pelas "regras" e "recursos lucrativos" que os espaços demarcados possuem. A quebra de regras firmadas em acordos de pesca, por pessoas da comunidade ou de fora, são entendidas como ameaças graves que ferem os direitos de quem é usuário e depende dos recursos naturais afetados. Há, assim, alguns tipos de conflitos comuns no ambiente aquático de acesso restrito às comunidades ribeirinhas, como ocorre no lago Caiau, envolvendo diferentes atores, causas e consequência, as quais estão sistematizadas no Quadro 1.

Para entendermos os atores que participam do conflito representado no Quadro 1, as causas e consequências, partimos da compreensão do primeiro grupo formado por “pescadores de subsistência”. Esses são os indivíduos que pescam principalmente para comer, vez ou outra vendem os excedentes, mas para eles a pesca não é uma profissão. Esse grupo é formado majoritariamente por pessoas mais idosas que não tiveram o hábito de comercializar. 
PAIVA, E. J. S.; SILVA, R. G. C.

Territórios pesqueiros na Amazônia:dinâmica de pescadores comerciais e de subsistência em comunidade ribeirinha da tríplice fronteira Colômbia-Brasil-Peru

O segundo grupo é composto pelo "pescador comercial interno". Esses indivíduos realizam a pesca comercial tanto em lagos comunitários (essa categoria tem permissão para pescar nos ambientes de acesso restrito à comunidade em que vive, justamente por ser morador dela), como em outros ambientes de livre acesso (rio Solimões, por exemplo). Esses pescam principalmente para vender, consomem apenas uma pequena parcela daquilo que produzem. Para eles a pesca é uma profissão.

Quadro 1: Conflitos existentes em lagos comunitários de acesso restrito (lago Caiau)

\begin{tabular}{|c|l|l|}
\hline Atores do conflito & \multicolumn{1}{|c|}{ Causas } & \multicolumn{1}{|c|}{ Consequências } \\
\hline $\begin{array}{c}\mathbf{X} \\
\text { Pescador de subsistência }\end{array}$ & $\begin{array}{l}\text { Desrespeito aos acordos de de } \\
\text { pesca que regularizam pescarias } \\
\text { em ambientes de uso } \\
\text { compartilhado }\end{array}$ & $\begin{array}{l}\text { Discussones verbais, denúncias e } \\
\text { promessas de agressões físicas }\end{array}$ \\
\hline $\begin{array}{c}\text { Pescador de subsistência } \\
\text { Pescador comercial externo }\end{array}$ & $\begin{array}{l}\text { Invasão das áreas delimitadas; } \\
\text { pesca ilegal }\end{array}$ & $\begin{array}{l}\text { Ameaças de pescadores } \\
\text { externos; medo por parte dos } \\
\text { pescadores de subsistência }\end{array}$ \\
\hline $\begin{array}{c}\text { Pescador comercial interno } \\
\mathbf{X}\end{array}$ & $\begin{array}{l}\text { Disputa pelos territórios de } \\
\text { pesca }\end{array}$ & $\begin{array}{l}\text { Discussões verbais, brigas e } \\
\text { ameaças de morte }\end{array}$ \\
\hline Pescador comercial externo & & \\
\hline
\end{tabular}

Fonte: Pesquisa de campo, 2019.

Diferentemente do terceiro grupo, formado por "pescadores comerciais externos". Esses não estão autorizados a pescar em ambientes de acesso restrito às comunidades, visto que, não tem direitos de utilizar esses espaços por ser "alheio" a ele. Os ambientes de livre acesso seriam essencialmente seus territórios permitidos (rios). Esses são pescadores tabatinguenses, peruanos e colombianos que desrespeitam locais delimitados em busca de boas capturas.

As causas dos conflitos costumeiramente ocorrem pelo desrespeito mútuo entre pescadores do grupo $2^{\circ}$ e $3^{\circ}$, o que interfere no uso de territórios restritos e na quebra dos acordos de pesca. O não reconhecimento ou negação existencial dos territórios pesqueiros levam à invasão desses ambientes pela "ultrapassagem do território alheio", o que origina as consequências listadas no Quadro 1. Embora o Sindicato de Pescadores, Colônias de Pesca e os próprios sujeitos estabeleçam "acordos de pesca" com o objetivo de não gerar conflitos, ou mesmo abrandá-los, estes, continuamente, não são cumpridos e dão efeito contrário à conciliação. 

ribeirinha da tríplice fronteira Colômbia-Brasil-Peru

Os mais afetados são os pescadores de subsistência, pois para estes, o lago é visto como uma "geladeira" que guarda o alimento diário. A interferência de invasores lhes da sensação de ser saqueado na própria casa. Os pescadores de subsistência de Terezina III não tem costume e condições de migrar para pescar em outras áreas (longa distância e cansaço físico). Assim, para estes, o desequilíbrio e conflito causado nos lagos não é visto, a princípio, como perda comercial e sim de sobrevivência, afeto, pertencimento. Os outros dois grupos são atingidos, sobretudo, comercialmente (não negamos que pode haver o sentimento de afeto e pertencimento com o lago). Para eles a solução é buscar alternativas (percorrer áreas mais distantes, aumento de combustível e gelo para armazenagem, mais horas de trabalho e longe de casa) que certamente requerem mudanças significativas na rotina de trabalho.

Pelas disputas recorrentes, o aumento do quantitativo pescado se torna evidente, visto que, uma categoria quer se "sobressair" ao capturar mais peixes que a outra e obter mais lucro ao comercializar. Esse aumento na captura passa a ser um dos principais motivos intensificadores da pesca predatória em lagos comunitários, principalmente, em função da ação dos pescadores comerciais internos e externos, enquanto os de subsistência são os mais impactados por essas ações continuamente exploratórias.

Os conflitos apresentados possuem temporalidade que margeia ao menos três décadas, mas com alta intensidade nos últimos dez anos pela imposição do capital sobre as comunidades ribeirinhas de pescadores. Nisso, os dados do quadro anterior foram elaborados a partir do roteiro de identificação dos conflitos entre os três grupos na comunidade. Assim, foram apresentadas as categorias e tipos de conflitos mais citados pelas comunidades estudadas. A participação da comunidade foi importante para compreensão da realidade, embora alguns apresentassem receio em comentar sobre o assunto, a maioria não teve dificuldade em dialogar e fornecer informações. A maior parcela desses conflitos, embora pretéritos, ainda possuem consequências destruidoras.

Nesse contexto, um fator importante analisado em comunidades ribeirinhas é o significado cultural e de identidade na relação ribeirinha: a pesca. O hábito de possuir apetrechos, arrumar a canoa e sair para pescar são ações cotidianas que intimamente manifestam identidade e caracterizam a vida cultural do pescador ribeirinho. Esses indivíduos, então, passam a viver sob dimensões sociais de espaços em que as crenças, mitos, sonhos e realidades dão sentido para a produção e reprodução da condição de ser "pescador". 
PAIVA, E. J. S.; SILVA, R. G. C.

Territórios pesqueiros na Amazônia:dinâmica de pescadores comerciais e de subsistência em comunidade ribeirinha da tríplice fronteira Colômbia-Brasil-Peru

Portanto, todas as influências contraproducentes que modificam o espaço vivido e interferem na dinâmica diária dos grupos sociais são ações que fragilizam o modo de vida dessas comunidades (Figura 4).

Figura 4: Famílias de pescadores comerciais chegando ao porto de Tabatinga (2019)

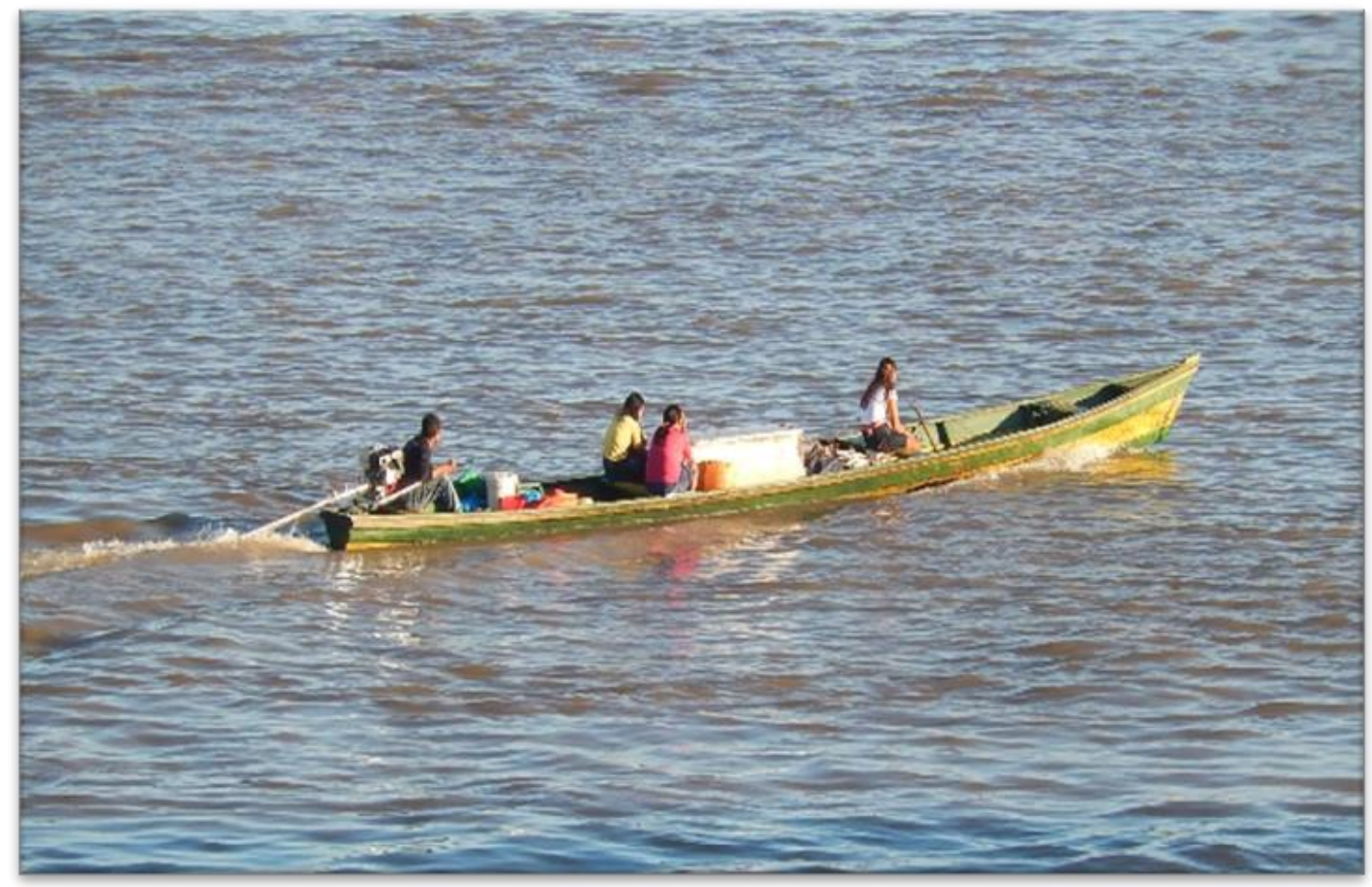

Fonte: Pesquisa de campo, 2019.

Por fim, as dinâmicas sociogeográficas das comunidades ribeirinhas da Amazônia se constituem na relação dos grupos com a natureza, configurando-se em territórios pesqueiros. Esse processo alcança equilíbrio quando a atividade produtiva, geradora de trabalho e renda, não é demasiadamente pressionado por fluxos mercantis externos. Quando as variáveis externas se internalizam nas comunidades, nos territórios pesqueiros, a solidariedade orgânica se fragiliza (SANTOS, 2000), erodindo a capacidade dos grupos em se verem de modo coletivo para fazer frente ao domínio do capital comercial - atravessadores que tende a influenciar a vidada coletiva, o vivido territorial, dessas comunidades. No caso analisado, o mercado é o "agente" motivador da exploração mais intensiva dos recursos do território, sendo necessário certa convergência na gestão desses espaços para que as comunidades não sejam fragilizadas em seu cotidiano, que envolve trabalho, renda, comunidade e comunhão. 
Territórios pesqueiros na Amazônia:dinâmica de pescadores comerciais e de subsistência em comunidade ribeirinha da tríplice fronteira Colômbia-Brasil-Peru

\section{CONSIDERAÇÕES FINAIS}

As lutas firmadas por comunidades ribeirinhas que vivem e utilizam o ecossistema na Amazônia têm como principal objetivo proteger os recursos naturais, sobretudo os pesqueiros, que vem passando por longo processo de exploração desordenada e crescente na pesca comercial. Além disso, o crescimento da produção pesqueira tem gerado conflitos entre as categorias de pescadores, notadamente pelo uso e apropriação do território.

Deste modo, este trabalho buscou problematizar algumas questões sociais e ambientais que vêm ocorrendo na comunidade ribeirinha Terezina III, cujos conflitos pelo acesso, uso e apropriação do território têm importância social para essas comunidades. Contudo, compreendemos que são espaços de difícil ordenamento, pois, além de comportarem grande extensão territorial, apresentam a junção de três países que formam uma tríplice fronteira, que une costumes, crenças, ideologias, culturas e saberes que, consequentemente, nem sempre estarão em sintonia e respeitarão os territórios demarcados.

De modo geral, compreende-se que a ação do Estado brasileiro em regiões de fronteira, sobretudo em atendimento às comunidades tradicionais, deve priorizar a atenção social (saúde, educação) e econômica (produção, transportes) para que as atividades produtivas e os territórios tradicionais possam estar cada vez mais adequados às condições de vida e de defesa da natureza. As comunidades ribeirinhas já demostraram capacidade de preservação ambiental, contudo, as escalas econômicas têm potencial elevado para pressionar de modo regressivo a sustentabilidade dos territórios tradicionais. Em muitos casos, esse processo se mostra avassalador na Amazônia.

Para a ciência geográfica, há um universo social, cultural e natural a ser pesquisado, um mundo a ser entendido que se chama Amazônia. Essa região é formada por mosaicos espaciais que elencam desde metrópoles, cidades médias, cidades regionais, pequenas cidades e povoados, ao mundo rural, configurado em espaço agrário, florestal, das águas (rios e lagos) e dos povos amazônicos, no qual vivem milhares de famílias. Esse universo ribeirinho é por demais complexo, exigindo metodologias compatíveis à leitura da complexidade sociogeográfica que modelam a Amazônia mais profunda.

Se pensarmos que nos limites fronteiriços com vários países que margeiam a Amazônia brasileira, pode-se argumentar que se trata de uma região muito narrada como 
PAIVA, E. J. S.; SILVA, R. G. C.

Territórios pesqueiros na Amazônia:dinâmica de pescadores comerciais e de subsistência em comunidade ribeirinha da tríplice fronteira Colômbia-Brasil-Peru

periferia do Brasil. Contudo, nesse universo, há relações sociais, políticas, econômicas e culturais que dinamizam e tensionam a vida na fronteira, cuja expressão espacial é o universo de rios e florestas, dos povos amazônicos, que sentem os desafios e pressões externas que cada vez mais alcançam os territórios tradicionais.

Assim, as contribuições assentadas neste trabalho buscam entender os territórios pesqueiros como expressão das comunidades ribeirinhas na tríplice fronteira no universo amazônico das águas. Como demonstrado, o território pesqueiro pode ser compreendido por meio do estudo das dinâmicas do trabalho nas comunidades ribeirinhas, e pelo uso diário do lago por diversos atores sociais que tecem toda uma vida junto aos encontros e desencontros que a atividade pesqueira presenteia.

\section{AGRADECIMENTOS}

A pesquisa contou com apoio das instituições: Conselho Nacional de Desenvolvimento Científico e Tecnológico (CNPq) e Fundação Rondônia de Amparo ao Desenvolvimento das Ações Científicas e Tecnológicas e à Pesquisa (FAPERO).

\section{REFERÊNCIAS}

ADAMS, C. (org) et al. Sociedades Caboclas Amazônicas: Modernidade e Invisibilidade. São Paulo, FAPESP, 2006.

ALMEIDA, O. T. O manejo de pesca na Amazônia brasileira. São Paulo: Peirópolis, 2006. BARTHEM, R. B. GOULDING, M. Os Bagres Balizadores: ecologia, migração e conservação de peixes amazônicos. Tefé: Sociedade Civil Mamirauá; Brasília: CNPq, 1997.

CAVAlCANTE, M. M. A; NUNES, D. D; COSTA SILVA, R. G; LOBATO, L. C. H. Políticas Territoriais e Mobilidade Populacional na Amazônia: Estudo sobre as Hidrelétricas de Jirau e Santo Antônio no Rio Madeira/ Rondônia/Brasil. In: XVI ENCONTRO NACIONAL DE ESTUDOS POPULACIONAIS. Anais... Caxambú: ABEP, 2008. pp. 3-18.

COSTA SILVA, R. G. Espaço, sociedade e natureza em Rondônia. Revista Geoamazônia, [S./l.], v. 1, p. 144-165, 2014. Disponível em: 〈http://dx.doi.org/10.17551/23581778/geoamazonia.n2v1p144-165>.

COSTA SILVA, R. G.; NEVES, J. G. Território, Direitos Humanos e Educação do/no campo na Amazônia. Revista de Educação Pública (UFMT), Cuiabá, v. 27, p. 635-655, 2018. Disponível em:

<http://periodicoscientificos.ufmt.br/ojs/index.php/educacaopublica/article/view/6887/4458 >. 
PAIVA, E. J. S.; SILVA, R. G. C.

Territórios pesqueiros na Amazônia:dinâmica de pescadores comerciais e de subsistência em comunidade ribeirinha da tríplice fronteira Colômbia-Brasil-Peru

CRUZ, M. J. M. Rios e Lagos: apropriação da pesca pelos camponeses-ribeirinhos na Amazônia. in: BRAGA, Sérgio Ivan Gil. (org.) Cultura Popular, Patrimônio Material e Cidades. Manaus: EDUA, 2007.

CUNHA, G. D. O. B.; COSTA SILVA, R. G. Invisibilidades produzidas: o "desaparecimento" das comunidades ribeirinhas nos estudos da hidrelétrica Tabajara (Amazônia brasileira). Revista Interdisciplinar de Direitos Humanos, Bauru, v. 7, p. 95116, 2019. Disponível em: <https://www3.faac.unesp.br/ridh/index.php/ridh/article/view/713/321 >.

DIEGUES, A. C. S. O mito moderno da natureza intocada. São Paulo: NUPABUSP, 1994.Disponivel em: <https://periodicos.ufpa.br/index.php/ncn/article/view/450>. Acessado em: 30 set. 2020.

BARTHEM, R. B.; GOULDING, M. Os bagres balizadores: ecologia, migração e conservação de peixes amazônicos. Tefé: Sociedade Civil Mamirauá; Brasília: CNPq, 1997.

EUZÉBIO, E. F. Fronteira e horizontalidade na Amazônia: as cidades gêmeas de Tabatinga (Brasil) e Letícia (Colômbia). 2011. 168 f. Dissertação (Mestrado em Geografia Humana), Universidade de São Paulo, Departamento de Geografia, São Paulo, 2011.

FREITAS, C. E. C. RIVAS, A. A. F. A pesca e os recursos pesqueiros na Amazônia ocidental. Ciência \& Cultura, 2006.

GOTTMANN, J. The evolution of the concept of territory. Social Science Information, [S./l.], v. 14, n. 3, ago. 1975, p. 29-47.

HAESBAERT, R. Viver no limite: território e multi/transterritorialidade em tempos de insegurança e contenção. 1. ed. Rio de Janeiro: Bertrand Brasil, 2014.

IBGE. Portal Cidades e Estados. Município de Tabatinga - Panorama, 2020. Disponível em: $<$ https://cidades.ibge.gov.br/brasil/am/tabatinga/panorama $>$.

MACHADO, L. O. Mitos e realidades da Amazônia brasileira no contexto geopolítico internacional (1540-1912). 1989. 512 f. Tese (Doutorado em Geografia), Departamento de Geografia Humana/Universidade de Barcelona, Barcelona, 1989.

MORAES, A. O; SCHOR, T; ALVES-GOMES, J. A. O Mercado de Bagres e a Configuração da Rede Urbana no Alto e Médio Solimões, Amazonas, Brasil. Caderno Prudentino de Geografia. [S./1.], v.1, n.32, p.93-110. 2010a. Disponível em: <http://agbpp.dominiotemporario.com/doc/CPG32A-8.pdf>.

MORAES, A. O; SCHOR, T; ALVES-GOMES, J. A. Relações de Trabalho e Transporte na Pesca de Bagres no Rio Solimões -AM. Novos Cadernos NAEA, [S./1.], v. 13, n.1, p.155170.2010b. Disponível em: 〈https://periodicos.ufpa.br/index.php/ncn/article/view/450>. 
MORAES, A. O. Peixes, redes e cidades: aspectos socioambientais da pesca comercial de bagres no Médio e Alto Solimões - AM. 2012. 140 f. Dissertação (Mestrado em Ciências do Ambiente e Sustentabilidade na Amazônia) - Universidade Federal do Amazonas, Manaus, 2012. Disponível em: 〈https://tede.ufam.edu.br/handle/tede/2533〉.

PAIVA, E. J. S. Notas iniciais sobre "rios tradicionalmente ocupados": formas de uso e manutenção dos saberes da pesca na Amazônia. In: COSTA SILVA, R. G; LIMA, L. P; CONCEIÇÃO; F. S. (Org.). Amazônia: dinâmicas agrárias e territoriais contemporâneas. 1ed., São Carlos - SP: Pedro \& João Editores, 2018, v. 1, p. 287-308.

PAIVA, E. J. S. Territórios Pesqueiros: a pesca comercial e o co-manejo pesqueiro em comunidades ribeirinhas da microrregião do Alto Solimões/Amazonas. 2019. 152 folhas. Dissertação, Programa Pós-Graduação Geografia (PPGG) - Universidade Federal de Rondônia - UNIR, Porto Velho, 2019.

PAIVA, M. P. Administração pesqueira no Brasil. Rio de janeiro: Interciência, 2004.

PETRERE JR, M. A pesca comercial no rio Solimões-Amazonas e seus afluentes: análise dos informes do pescado desembarcado no mercado municipal de Manaus (1976-1978). Manaus: Ciência e cultura, 1985.

PORTO, M. F; PORTO, P. S. S. Conflitos por Água no Brasil e a Defesa dos Comuns: uma leitura a partir da Ecologia Política e da experiência do Mapa de Conflitos envolvendo Injustiça Ambiental e Saúde. 2020. Disponível em: http://conexaoagua.mpf.mp.br/arquivos/artigos-cientificos/2016/14-conflitos-por-agua-nobrasil-e-a-defesa-dos-comuns.pdf. Acesso em: 07.06.2020.

PROVARZEA, Projeto Manejo dos Recursos Naturais da Várzea/ Ibama. A pesca na região Amazônica: debates para uma possível solução/Projeto Manejo dos Recursos Naturais da Várzea/Ibama. - Brasília: Ibama, 2005.

RAFFESTIN, C. Por uma geografia do poder. São Paulo: Ática. 1993.

RAGGI ABDALLAH, P. Atividade pesqueira no Brasil: Política e evolução. 1998. 148 f. Tese (Doutorado em Ciências. Área de concentração: Economia Aplicada) - Escola Superior de Agricultura Luiz de Queiroz/ USP, São Paulo, 1998.

RAMALHO, C. W. N. Pescados, pescarias e pescadores: notas etnográficas sobre processos ecossociais. Boletim do Museu Paraense Emílio Goeldi. Ciências Humanas, Recife, v. 11, n. 2, p. 391-414, maio-ago. 2016.

RAPOZO, P. Territórios sociais da pesca: usos e formas de apropriação comum dos recursos pesqueiros em áreas de livre acesso. Manaus: EDUA, 2015.

REZENDE, Tadeu Valdir Freitas de. A conquista e a ocupação da Amazônia brasileira no período colonial: a definição das fronteiras. 2006. $353 \mathrm{f}$. Tese (Doutorado em História), Departamento de História Econômica, FFLCH, USP, São Paulo, 2006. 
PAIVA, E. J. S.; SILVA, R. G. C.

Territórios pesqueiros na Amazônia:dinâmica de pescadores comerciais e de subsistência em comunidade ribeirinha da tríplice fronteira Colômbia-Brasil-Peru

RUFFINO, M. L. Gestão do uso dos recursos pesqueiros na Amazônia. Manaus: IBAMA, 2005.

SANTOS, M. O espaço dividido: os dois circuitos da economia urbana dos países subdesenvolvidos. Rio de Janeiro: Francisco Alves, 1979.

SANTOS, M. Por uma outra globalização: do pensamento único à consciência universal. São Paulo: Record, 2000.

SAQUET, M. A. As diferentes abordagens do território e a apreensão do movimento e da (i)materialidade. Geosul, Florianópolis, v. 22, n. 43, p. 55-76, jan./jun. 2007.

SCHERER, E. Mosaico Terra-Água: a vulnerabilidade social ribeirinha na Amazônia Brasil. In: VIII Congresso Luso-Brasileiro de Ciências Sociais; Coimbra, POR.

Universidade de Coimbra, 2004.

SCHWADE, T. M. M. O território agrário ao longo dos rios no Amazonas. REVISTA CERRADOS (UNIMONTES), Montes Claros, v. 17, p. 96-125, 2019. Disponível em: <https://doi.org/10.22238/rc24482692201917029612 >. Acessado em: 28 set. 2020.

SILVA, C. N. Geografia e representação espacial da pesca na Amazônia paraense. 1. ed. - Belém: GAPTA/UFPA, 2012.

\section{Autores}

Erlainy Joanna Souza de Paiva - É Graduada em Geografia pela Universidade do Estado do Amazonas (UEA) e Mestrado em Geografia pela Universidade Federal de Rondônia (UNIR). Atualmente é Pesquisadora do Núcleo de Estudos Socioambientais da Amazônia NESAM/UEA/Tabatinga.

Ricardo Gilson da Costa Silva - É Graduado e Mestre em Geografia pela Universidade Fedral de Rondônia (UNIR), Doutor em Geografia Humana pela Universidade de São Paulo (USP) e Posdoctorado en Ciencias Humanas y Sociales pela Universidad de Buenos Aires (UBA). Atualmente é Professor do Departamento de Geografia (DGEO), do Programa de Pós-Graduação em Geografia (PPGG) e do Programa de Pós-graduação Mestrado Profissional Interdisciplinar em Direitos Humanos e Desenvolvimento da Justiça (DHJUS) da Universidade Federal de Rondônia (UNIR).

Artigo recebido em: 13 de agosto de 2020.

Artigo aceito em: 09 de novembro de 2020.

Artigo publicado em: 13 de novembro de 2020. 